\title{
The Effectiveness of Community-Based Early Warning System of Kelud Volcano Eruption
}

\author{
Yi, Waonho*, Yohana Naradika Maharani**, Kim, Jitae ${ }^{* * *}$, and Lee, Sungsu****
}

\begin{abstract}
This research is a study on effective disaster countermeasures such as awareness of volcano eruption and continuous evacuation training by continuous education and management through rapid response system through early alarm system according to volcanic eruption and community resiliency process. In the case of the successful introduction of the early warning system and the social reconstruction process at the time of the eruption of Kelud volcano in Indonesia in 2013 enabled evacuation without casualties, thus confirming the importance of systematic management of the volcanic area according to local characteristics. Therefore, it is expected that volcanic eruption will be actively responded to and applied to other volcanic eruptions by systematic management and system introduction.
\end{abstract}

Key words : Volcano Eruption, Early Warning System, Community Resiliency Process

\section{요 지}

본 연구는 화산분화에 대한 조기경보시스템과 사회복원 구축 프로세스를 통해 지속적인 교육 및 관리를 통해 신속한 대응 및 효율적인 재난 대응 방법 적용에 관한 연구이다. 실제로 2013년 인도네시아의 Kelud 화산 분화 당시 조기경보시스템 및 사회복원 구축 프로세스의 성공적인 도입으로 사상자 없는 대피가 가능했고 이를 통해 지역 특성에 맞는 화산지역의 체계적인 관리의 중요성을 확인할 수 있었다. 따라서 다른 화산분화 위험지역에 대해서도 체계적인 관리 및 시스템 도입을 통해 화산 분화에 대한 적극적인 대응 및 활용을 기대해 본다.

핵심용어 : 화산폭발, 조기경보시스템, 지역 사회 복원 구축 프로세스

\section{Introduction}

Kelud Volcano is an active volcano erupted on 13 February 2013 in Indonesia. Local people were successfully responded the biggest eruption in history without any fatalities, by doing less than 2 hours evacuation. Analysis on building community resiliency process showed that four aspects of early warning system have been successfully fulfilled by local authorities and the villagers. Those four aspects are (1) Knowledge of risk (2) Monitoring and warning services (3) Dissemination and communication (4) Ability of the people to response. Systematic data collection and risk assessment, with its pattern and tendency factors ensured that disaster and vulnerability are well-known (Blaikie et al., 1994). In community level, risk assessment and disaster introduction with its factors have been introduced since 2007. Monitoring parameter, strong basic and scientific to create accurate and timely pre-estimation has been ensured by disaster monitoring and early warning service. In national authority level, Volcano Observatory implemented dissemination. Spatial dissemination and status change dissemination which are offered in Disaster-Prone Area Map (Cas and Wright, 1987).

\section{Method of study}

This work aimed to reveal the successful of residents in

\footnotetext{
* Member, Professor, Department of Architectural Engineering, Kwangwoon University(E-mail: whyi@kw.ac.kr)

** Dr, Department of Civil Engineering, UPN "Veteran" Yogyakarta, Indonesia

*** Corresponding Author, Member, CEO, SDM ENC Co., Ltd (Tel: +82-2-6959-9580, Fax: +82-2-6959-9589, E-mail: jtkim77777@hanmail.net)

**** Member, Professor, Department of Civil Engineering, Chungbuk University
} 
eruption-prone area of Kelud Volcano, as well as to obtain another success in applying community-based early warning system (Andreastuti et al., 2017). This research has been implemented through documentaries and exploratory study on community practice and relevant parties both before and after emergency condition. Documentaries study has been implemented by reread the program document which is implemented together with the people in disaster-prone area since 2007 to 2014. Exploratory study is done through direct interview and giving questionnaire on 90 people in disaster-prone area and standby team member in Malang, Blitar, and Kediri regencies as representative.

\section{Disaster risk reduction effort}

When Kelud's status increase in 2007 the Indonesian Society of Nature Lovers (Kappala) Entrepreneurs with Disaster Management Study Center, PSMB UPN "Veteran" (Pusat Studi Manajamen Bencana Universitas Pembanguana Nasional) and Oxfam GB (Headquaters are in Cowley, Oxford) had the opportunity to enter Sugihwaras and Sempu disaster-prone villages in Kediri District Penataran villages and Sumberasri in Blitar (Maskrey, 1989). From the discussion with the people, it was found that the community had built the preparedness by building a shelter from woven bamboo in front of their respective house which will be used to take shelter in case of eruption, the community will not leave their house because after the eruption is complete it will immediately clean the roof of the material so that the roof load is not too heavy (UNDRC, 1985).

\subsection{Dissemination programs in the level of district and village}

In the middle of 2008, Kappala Indonesia together with PSMB UPN "Vetaran", Oxfam and Troicare built preparedness in Kelud area. DRR (Disaster Risk Reduction) activities are new activities for the community. After the 2007 eruption there has been no disaster activity in the community. Activity begins with the blow.

\subsubsection{District level dissemination}

District-level dissemination activities were carried out in three districts of Kediri, Blitar and Malang. The purpose of this activity is to submit an activity plan that will be implemented around Kelud and ask for input in the implementation process.

\subsubsection{Village level dissemination}

Village level dissemination was carried out in 10 villages namely Sumberasri, Penataran, Candirejo villages in Blitar District; Sempu, Sugihwaras, Sepawon, and Besowo villages in Kediri Regency; villages of Pondokagung, Ngantru, Pandansari in Malang Regency (van Bemmelen, 1949). In this activity delivered the condition of Kelud post eruption 2007 and plan activities to be done. To encourage public awareness, Kappala Indonesia, involving Pasag Merapi from the Merapi area to tell what has been done in Merapi in maintaining the preparedness for living in disaster prone areas.

\subsection{Building community and government synergy}

Efforts to build synergies are conducted through district-level workshops, series of training and capacity building and drafting the working groups of each district.

\subsubsection{District-level workshops}

This activity is carried out in each district, in the form of the first meeting between the community and government representatives. The discussion was conducted to discuss the handling of Kelud post-eruption 2007. From this activity it was agreed who should be involved in the upcoming activities both representatives from the government and from the community, as well as the process of delivering invitations.

\subsubsection{Training / capacity building series}

Several activities for capacity building on disaster management, emergency management, gender in DRR, training of contingency planning and mapping of digitization are conducted jointly between government and community representatives. The training aims to build synergy in disaster reduction activities between government and society. (Blaikie et al., 1994) The process of building synergy between the community and the government is also done outside the training room by exercising together. This activity is carried out in the hope of removing the partition between government and society.

\subsubsection{Working groups of each district}

To strengthen the relationship between the community and the government by forming a working group in each district by scheduling meetings to formulate a work plan that can be done. 


\subsection{Building community preparedness}

Capacity building process and awareness building on disaster risk management in the community started in 12 villages with local trainers at village level. Facilitators of DRR actors are selected to encourage public awareness. Pasag Merapi was asked to be a facilitator and also a motivator of Kelud residents to conduct Community Based Risk Management (CBDRM / PRBBK) activities. PMI (Indonesia Red Cross) is requested to submit an Emergency Patient Handling Material (PPGD) in cooperation with Puskesmas and community with other elements in DRR activities (The UN Refugee Agency, 2000). From these training resulted the risk analysis document, evacuation plan, soup, mapping and formed the village alert team. Work at the community level continues through the establishment of local facilitators, developing villages, integrating DRR materials in schools, and building models and props, with the following details

\subsubsection{Local facilitators}

The "virus" spreader of PRBBK becomes an option to speed up and simplify the process. Representatives of village alert teams are training to become facilitators of virus spreaders in new villages with PRBBK and PPGD materials.

\subsubsection{Developing a village}

The training was conducted in villages around Kelud facilitated by members of the village alert team who had trained as facilitators, from the initial 12 villages that had formed the village alert team developed into 36 villages, in addition to the new villages also doing local coaches in the old village in order to increase the alert team.

\subsubsection{Integrate DRR materials in school subjects}

To become a disaster-prone area is not enough with the activities in the village but must involve all parties located kelud area. Schools are among the parties involved, involving representatives of teachers in DRR training so as to be able to analyze their school risks and prepare preparedness plans as well as integrating DRR materials on subjects.

\subsubsection{Developing props in children's DRR}

Dolls become one of the tools for delivering DRR materials for children, kindergarten and elementary school teachers practicing together about DRR and playing puppets as a method to convey to their students, practice moving puppets, making stories and interacting with their students.

\subsubsection{Compile modules}

By practicing and practicing recording what has been done, the facilitators write their experiences in facilitating the local trainer into a joint module. The hope can be used as guidance and reading materials for other people to do local training.

\subsection{Community organization Jangkar Kelud}

Jangkar Kelud believes that good disaster risk reduction is the responsibility of all parties and is carried out all the time before disaster occurs, during a disaster and after a disaster, and in disaster risk reduction activities should be community based, as the community as the beneficiary directly, as weak as the community still has the ability to conduct disaster risk reduction activities, the community is better understood its territory, but it does not cover the role of other parties either government, business community, or other institutions committed in the case of disaster risk reduction. In collaboration with Kappala Indonesia PSMB UPN "Veteran" Yogyakarta, Jangkar Kelud conducts community capacity building programs for disaster risk reduction.

\subsubsection{Community based disaster risk reduction training}

Local training activities conducted in each village aimed at understanding disaster, recognizing threats, threat characteristics, analyzing risks, capacities and vulnerabilities, creating village disaster management protocols / SOPs (Standard Operating Procedure), creating Action Plans, creating district maps, and agreeing on an early warning system.

\subsubsection{Local emergency response workshops}

PPGD is the strengthening of community capacity in subscribing to patients before getting medical treatment. With this activity it is expected that the community has the ability to provide first aid properly before being handled by the medical.

\subsubsection{Mapping of disaster risk areas}

Each village mapping its territory to determine the location, boundaries, vulnerability, distance from threats, capacities and vulnerabilities from 6 aspects of life (human, social, political, infrastructure, economy, environment) as well as evacuation routes, become a source of information for the community as well as other parties. (Fig. 1) 


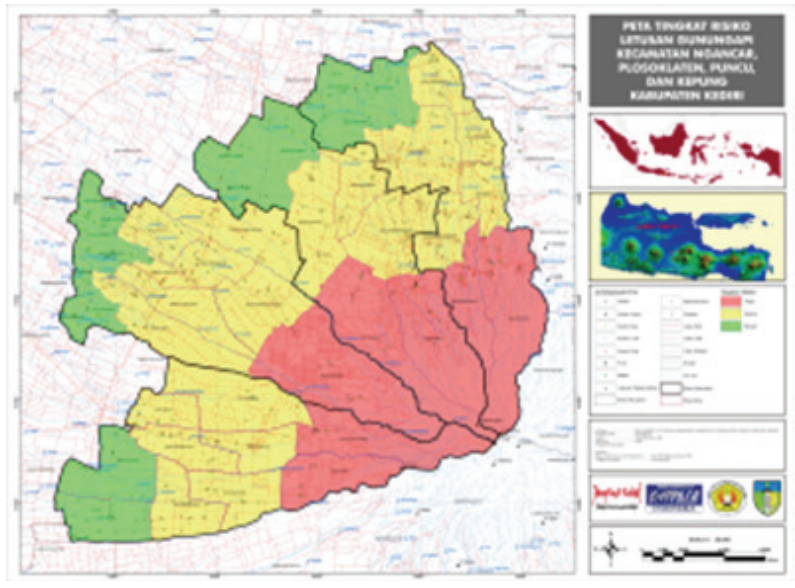

Fig. 1. Kelud Risk Map Covers Ngancar, Plosoklaten, Puncu, Kepung-Kediri

※ source: Jangkar Kelud

\subsubsection{Institutional strengthening of Village Alert Teams}

In community-based disaster risk reduction activities, institutions have an important role, village alert teams, a team of people who already have skills and knowledge about CBDRR and PPGD, are the coordinating and handling of disaster at the village level.

\subsubsection{Working group Jangkar Kelud}

Working group is a place to gather and discuss all elements of society, government, business, and mass organizations involved in disaster risk reduction Kelud in Blitar, Malang and Kediri districts as a need to develop work plan and improvement activities has been done for the better handling of Kelud disaster in the future.

\subsubsection{Field Simulation and Field Rehearsal}

From village alert teams who have skills and knowledge in DRR activities, together with all elements of the community conduct joint exercises to test the established procedures (Prosedur Tetap) that have been developed and also to hone the skills and preparedness of the village alert teams. By conducting regular field activities it is desirable to have sensitivity from all elements of society in an emergency. (Fig. 2)

\subsubsection{School Based Disaster Risk Management Training}

The number of schools located in the area of disaster prone to create a separate problem of the school in handling disasters that occurs in school therefore it is necessary school-based disaster risk reduction activities. Activities un-

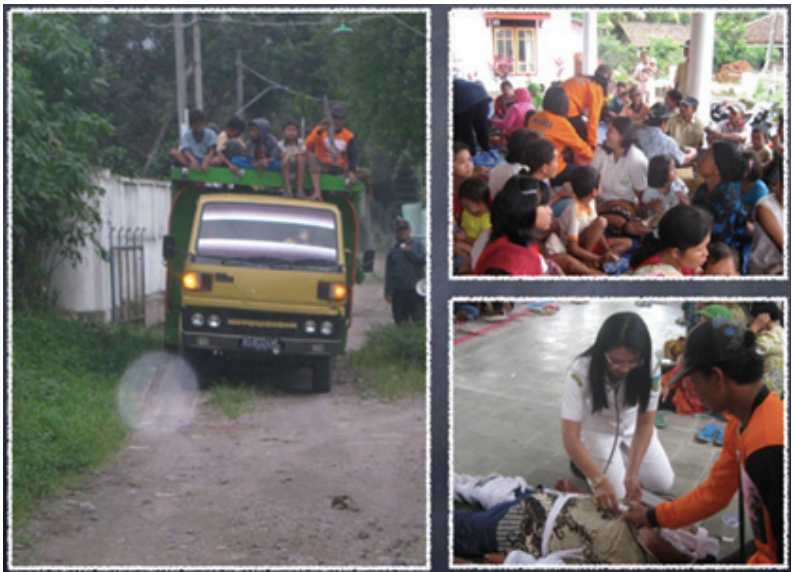

Fig. 2. Field Simulation and Activity Involving Many Parties ※ source: Jangkar Kelud

dertaken include capacity building of teachers on DRR and PPGD, preparing school protocols, preparing EWS in schools as well as integrating DRR materials in subjects.

\subsubsection{Early Warning System}

Information is fast and from the right source is very helpful in the preparedness of people who are in disaster prone areas. For preparedness, Jangkar Kelud has agreement of communication line by using HT (Handy talky) and community radio, there are 120 HT spread in 36 villages and 9 community radio that joined in Network Radio Community Anchor of Kelud.

\subsection{Maintaining substantiality}

Eliminating dependency can only occur if the institutional sustainability in the community and disaster risk management activities is carried out continuously. For that done to share trigger activities in the form of Disaster Preparedness Team, Joint Open event and Halal bi Halal / Berlebaran.

\subsubsection{Standby team meetings}

This event is filled with joint training on the readiness of competing PPGD between villages. With a competition to raise the activities of village alert teams, and given a gift of tools such as megaphone and handy talky.

\subsubsection{Open together and Halal bi Halal}

In the month of Ramadhan the members of the Jangkar Kelud team perform an open event together. This event is made to move where at home one of the members with the aim to establish silatuhrohmi also awaken the spirit of 
the standby team. Site selection is usually chosen by less active villages in the hope of being more active in the future. Halal bi Halal is used as a meeting place for alert team members in 3 districts to know each other and learn together. The event was held to invite stakeholders of BPBD (Local agency of disaster management)at district and provincial level, PVMBG and other parties who had joint activities both institutionally and individually.

\subsubsection{Establish a community-style early warning system}

Quick information and from the right sources are also a means of communication between the village alert teams that have expanded around Kelud become a common need. To meet these needs selected HT and community radio. There are 2 HTs in each village managed by the village alert team and 3 radiuses mounted on the slopes of Wilis (west side), on the slopes of Kawi (east side) and on the slopes of Arjuno for the north side. While the community radio that is managed by Jangkar Kelud there are 9 transmitting stations. With community radio, its hope can be used as a means of information and campaign on DRR when the conditions are safe and used for early warning what if there is an increase in the status of the mountain.

\subsubsection{Build networks}

This activity is done by visiting each other (Sambang Sedulur) and sharing experiences with other regions and other groups. (1) Sambang Sedulur is an activity to visit and study together with other communities often done in every activity, some communities that have been visited include Pasag Merapi, Panjer Manikoro and Kobar Bromo Semeru. Share experiences with other regions and other groups. (2) Sharing experiences. It is a medium for learning together with other areas to increase knowledge and increase awareness in disaster management. Some areas that have been studied together are flood-prone community of Ngasinan (Panjer Manikoro) watershed in Trenggalek regency, community of Bromo and Semeru mountain slopes (Kobar Bromo Semeru) in Malang, Pasuruan, Lumajang and Probolinggo districts. Banser Training of Kediri Regency, Bagana (Banser Siaga Bencana) of Madiun Regency, and Jawi Wetan Church Community of Pagu Sub-district of Kediri Regency.

\section{Results}

Analysis on the process of building resiliencies showed that all aspects of early warning system has been accomplished by the community and local authorities. Those four aspects are (1) risk knowledge, (2) Monitoring and warning service, (3) dissemination and communication, and (4) response ability. BNPB (National agency of disaster management), The Center for Volcanology and Geological Disaster Mitigation (PVMBG), BPBD (Local agency of disaster management) of respective province and regency are important authorities in national and regional level. In community level, Jangkar Kelud is rarely discussed within success in maintaining those four aspects.

BNPB, Geological Institute, through PVMBG are important authorities in national level. Meanwhile, in regional level, there are BPBD of Malang regency, Blitar regency, and Kesbanglimnas Kediri regency (as Kediri did not have agency for disaster management at that time). In community level, there is Jangkane Kawula Redi Kelud (Jangkar Kelud) as an important community-based disaster management organization. Since established in 9 August 2008, Jangkar Kelud with Kappala Indonesia community and Disaster research and management of UPN Veteran Yogyakarta started to initiate various activity on Community Based Disaster Management (CBDRM) in Kelud area.

\subsection{Risk assessment}

A systematic data collection and risk assessment showed that hazard and vulnerability has been known well. Pattern and trend of each factor are known, furthermore, data provision and risk mapping has been widely arranged. In 2013, BNPB obliged PSMB UPN Veteran Yogyakarta to arrange a blueprint on disaster management plan of volcanic eruption and targeted Kelud as one of the priority. Geological Institute and PVMBG were always monitored and researched it. In community level, risk assessment, hazard introduction, and influencing factors has been implemented since 2008. Meanwhile, series of disaster management training; emergency response training, school-based disaster management; community-based disaster management, aids on emergency patient, workshop and training on risk mapping and disaster contingency has been implemented within period of July 2008-May 2010. PVMBG, together with Kappala Indonesia community and PSMB UPN Veteran Yogyakarta were always involved in every capacity strengthening of Jangkar Kelud.

Those series of training were understood in form of relation between volcano status and community's responsiveness, relation of volcano status, PVMBG's recommendation and important activities in the community were formula developed 
in Obligatory Training on Volcanic Eruption Disaster Management of Merapi volcano with Geological Disaster Technology Research and Development Center (BPPTKG) and Forum Merapi, PASAG Merapi, PSMB UPN, and Kappala Indonesia.

\subsection{Monitoring and warning service}

Monitoring and early warning system have been ensured the truth of monitored parameter, created strong and scientific basis to make prediction, and created an accurate and on-time warnings. PVMBG implemented some dissemination of information. Spatial dissemination has been delivered in disaster risk mapping of Kelud. For 2014, information has been disseminated accurately. Status changing from Normal into Advisory was delivered in 2 February 2014; status changing from Advisory into Watch was delivered in 10 February 2014; status changing from Watch into Warning was delivered in 13 February 2014 at 21:15 and eruption occurred at 22:30.

\subsection{Dissemination and communication}

Communication and early warning system has ensured that the warning can reach everyone impacted, thus, disaster risk and its warnings can be understood, and it has clear and useful information. In community level, early warning system training in every river stream has been delivered in January 2009. Management, broadcasting, community radio technique training has been implemented in December 2011-June 2012. Meanwhile, radio information operating system and its communication tools (handy talky) has been implemented in April 2011.

A good information system flowed from one source through a specific way. Community can receive the information as one meaning and one interpretation, afterwards. A good information system flowed from communication radio, community radio, and cell phone. In 2014 eruption, monitoring post of Kelud communicated some changes from Watch into Warning to amateur radio organization, such as Amateur Radio Organization of Republic Indonesia (ORARI), or Radio Antar Penduduk Indonesia (RAPI) Kediri, and to Jangkar Kelud. Furthermore, Jangkar Kelud disseminated the information through phone, communication radio, and community radio into second order communication. Short communication order from monitoring post to the community has been delivered well. There are 13 community radio, 9 of them are Community Radio Network of Jangkar Kelud, prepared by Kappala Indonesia since 2010. Meanwhile, Kediri has community radio located in various locations; SugihWaras village (Kelud FM), Siman village (Adevo FM), Sempu village (Sempu Raya FM) and Satak village (JKS FM); In Blitar, they have community radio at Candirejo village (Candi Kelud FM), Modangan village (Lintas Kelud FM) and Soso village (Estu FM); Then, in Malang community radio are located in Pondokagung village (Pandawa FM) and Ngantru village (Smart FM). Each of them are supported by communication radio (handy talky). In 2013, there were 25 villages that reached by communication network, and now there are 63 villages. The radio is held by coordinator and representatives of each Standby village, as each of them have 20 members within. To ensure that information can be received, those communication radios are united by three repeaters which managed by Jangkar Kelud on the downhill of Wilis, Kawi, and Ngantang mountains. Meanwhile, Kediri has one repeater which built on Kelud.

\subsection{Response ability}

Building community responsiveness has been done by ensuring the response is always up-to-date. Then, local wisdom and knowledge can be utilized as they are ready to respond the warning. Communication network within 63 villages may enable them to work well. Simulation and training activity were implemented by community in the various village Sempu, Sumbersari, Pondokagung, Besowo, Candirejo, Pandansari, Ngantru, and Kepung. Those activities were held together with Kappala Indonesia from 2009-2011 and Banser $\mathrm{NU}$ in 2012 as their readiness to encounter the eruption.

\section{Conclusions}

Communicating information and early warning ensured that the warning can be received by everyone that affected by disaster, risk, and its warning can be understood and useful. A good information system will come from one source through specifically prepared channel. Short communication order from Kelud Volcano Observatory to people was ensured to be received unbiased.

Establishing the people's response to ensure the response alone must be renewed, ability and local knowledge can be utilized, and people are ready to response warning. Simulation and training activities were implemented by the people within disaster-prone area. Finally, the power of community preparedness may manage the huge level of volcano eruption.

Effectiveness and success of the people handling the 2014 Kelud eruption can be achieved through all parties who fulfill all aspects of early warning system. 
Fulfillment of all aspects of early warning system was long process of all parties, worked with community around prone area of Kelud since 2008.

Good practice of early warning system in Kelud must be acknowledged as a learning that resiliency is not an instant product and it is also improving knowledge that early warning system in not just a communication matter.

\section{Acknowledgements}

This research was supported by a grant [MOIS-DP-2015-07] through the Disaster and Safety Management Institute funded by Ministry of the Interior and Safety of Korean government.

\section{References}

Andreastuti, S., Budianto, A., and Paripurno, E.T. (2017) Integrating Social and Physical Perspectives of Mitigation Policy and Practice in Indonesia. Advances in Volcanology, Springer.
Blaikie, P., Cannon, T., Davis, I., and Wisner, B. (1994) At Risk: Natural Hazards, People Vulnerability, \& Disasters. Routledge, London \& New York.

Cas, R.A.F., and Wright, J.V. (1987) Volcanic Successions, Modern \& Ancient. Allen \& Unwin, London.

Maskrey, A. (1989) Disaster Mitigation: A Community Based Approach. Oxfam Print Unit, London.

The UN Refugee Agency (2000) Emergency Handbook. United Nations High Commissioner for Refugees (UNHCR), Tokyo.

UNDRC (United Nations Disaster Relief Coordinator) (1985) Volcanic Emergency Management. UN, New York.

Van Bemmelen, R.W. (1949) Geology of Indonesia. The Hague, Netherlands.

\begin{tabular}{|l|l|}
\hline Received & March 15, 2018 \\
\hline Revised & March 15, 2018 \\
\hline Accepted & March 26, 2018 \\
\hline
\end{tabular}


